\title{
Viral kinetics during the first month of treatment in patients with genotype 1 chronic hepatitis $\mathrm{C}$
}

\author{
A. Hernández, F. Domper, A. León ${ }^{1}$, R. Lorente, B. López, E. de la Santa, M. Cabanillas, R. Patón, \\ J. Olmedo, M. D. Galván and E. Rodríguez
}

Units of Digestive Diseases and 'Research Support. Hospital General de Ciudad Real. Spain

\begin{abstract}
Objective: to identify predictive factors of response to pegylated interferon alpha- $2 \mathrm{~b}$ and ribavirin in patients with genotype 1 chronic hepatitis C. Viral kinetics were studied in weeks 2 and 4.

Methods: a prospective and consecutive study of patients with genotype 1 chronic hepatitis $\mathrm{C}$ referred to our Hepatology Clinic between January 2004 and October 2006 for antiviral treatment. Baseline data were recorded and viremia levels were determined hours before the weekly dose of pegylated interferon by qualitative and quantitative PCR.

Results: 57 patients were included in the study, although 3 of these were excluded during follow up; $65 \%$ were male $(n=35)$, with a mean age of 42 (26-65) years. Baseline viremia levels were $>800,000 \mathrm{IU} / \mathrm{mL}$ in $67 \%(\mathrm{n}=36)$. Liver biopsy was performed in $86 \%(n=46), 22 \%(n=12)$ had advanced fibrosis. Forty were naïve, 4 relapsing and 10 non-responders. Ribavirin dose was modified in one patient alone due to adverse effects. End treatment response and sustained virological response (SVR) were 59 and $41 \%$, respectively. A univariate analysis revealed a statistically significant association of SVR with baseline viremia $(p=0.006)$, baseline GGT ( $p=0.025)$, and a reduction in viremia $\geq 2$ logs at 2,4 and 12 weeks $(p=0.001)$. The extent of viremia reduction at week 2 was associated with 100\% SVR, and at 4 weeks the positive predictive values was $84 \%$ and the negative predictive values was $96.5 \%$. A subanalysis of the naïve group yielded analogous results.
\end{abstract}

Conclusions: in our study, a reduction in viremia $\geq 2$ logs 2 weeks after treatment could ensure SVR. At 4 weeks, most non-responders could be identified.

Key words: Hepatitis C. Treatment. Pegylated interferon. Viremia. Predictive factors.

Received: 24-03-09.

Accepted: 26-05-09.

Correspondence: Francisco Domper Bardají. C/ Hospital de la Misericordia, 9, $5^{\circ}$ D. 13003 Ciudad Real, Spain. e-mail: franciscodomper@telefonica.net
Hernández A, Domper F, León A, Lorente R, López B, de la Santa E, Cabanillas M, Patón R, Olmedo J, Galván MD, Rodríguez E. Viral kinetics during the first month of treatment in patients with genotype 1 chronic hepatitis C. Rev Esp Enferm Dig 2009; 101: 671-679.

\section{INTRODUCTION}

Chronic hepatitis caused by hepatitis $\mathrm{C}$ virus (HCV) has a strong impact in our setting and is the most common cause of cirrhosis and liver carcinoma in Western countries (1). Today, the prevalence of HCV infection is $1-2 \%$ in developed countries, and it is the first indication for liver transplantation in Europe and the United States (2). Around $20 \%$ of patients with chronic infection will develop hepatic cirrhosis, with an annual risk of progression to hepatocellular carcinoma of 1-4\%.

Current therapy, based on pegylated interferon (pegIFN) and ribavirin (RBV), achieves an overall sustained virological response (SVR) of $54-56 \%$, thus improving disease prognosis $(3,4)$.

Therapeutic response can be influenced by patient characteristics, virus type, and treatment used. These variables help to identify the probable degree of response in each case, reducing unnecessary costs and side effects, improving adhesion to treatment, and helping to identify patients who could benefit from more intensive or prolonged treatment.

Viral kinetics (variations in viral load) during treatment is the most important factor predictive of response and can assist therapeutic decision-making. Early virological response (EVR) is defined as a reduction by at least $2 \operatorname{logs}$ of baseline viral load at week 12 of treatment. If EVR is not achieved, the probability of SVR is greatly reduced, with a predictive negative value (PNV) approaching $100 \%$, and today's clinical guidelines recommend treatment discon- 
tinuation $(5,6)$. Rapid viral response (RVR), defined as a negative viral load obtained at week 4, is a good predictive factor of SVR, with a positive predictive value (PPV) of 91\% (7-13). Although several studies have defined treatment duration, very few have assessed the value of viral kinetics early during the process.

The aim of this study was to identify which factors predict response to pegIFN alpha- 2 and RBV in patients with genotype 1 chronic hepatitis $\mathrm{C}$ infection, and to evaluate baseline virus- and host-related factors, especially the dynamic factors of viral kinetics in the second and fourth weeks of treatment.

\section{PATIENTS AND METHODS}

Patients with genotype 1 chronic hepatitis $\mathrm{C}$ referred to the Hepatology Clinic in our hospital between January 2004 and October 2006, and starting antiviral treatment with pegIFN alpha-2b and RBV were studied prospectively and consecutively.

Inclusion criteria were: age between 18 and 70, positive PCR in serum for HCV, ALT levels higher than normal $(\leq 40 \mathrm{IU} / \mathrm{L})$ in the past year. Exclusion criteria were: coinfection with HIV, HBsAg serology or positive hepatitis B viral DNA, contraindicated use of pegIFN or $\mathrm{RBV}$, decompensated cirrhosis, active IVDU, and patients recruited from prisons.

Patients received pegIFN alpha-2b (PegIntron; Schering Plough) at a dose of $1.5 \mu \mathrm{g} / \mathrm{kg}$ weight once a week subcutaneously, and RBV (Rebetol; Schering Plough) orally with weight-based dosing ( $<65 \mathrm{~kg}: 800 \mathrm{mg} /$ day; 65-85 kg: 1,000 mg/day; > $85 \mathrm{~kg}: 1,200 \mathrm{mg} /$ day) in fractionated morning and evening doses for 48 weeks.

Baseline clinical and laboratory data were recorded during treatment at weeks 2, 4, 8, 12, 16, 20, 24, 36 and 48 , and after treatment completion at week 72 . Viremia was determined hours before the weekly dose of pegIFN at weeks 2, 4, 12, 24, 48, 60 and 72 .

Viral load was measured using the Cobas Amplicor HCV Monitor 2.0 technique (detection limit of 600 $\mathrm{IU} / \mathrm{mL}$ ) until October 2005. Negative samples were submitted for qualitative RNA determination in Cobas Amplicor HCV Test, version 2.0 (sensitivity of $50 \mathrm{IU} / \mathrm{mL}$ ). After this time the technique used was COBAS Taqman $\mathrm{HCV}$ (sensitivity $15 \mathrm{IU} / \mathrm{mL}$, with quantitative determination up to $43 \mathrm{IU} / \mathrm{mL}$ ). A low baseline load was considered for $\leq 800,000 \mathrm{IU} / \mathrm{mL}(12,13)$.

$\mathrm{HCV}$ genotype was determined using the Inno-lipa II technique (Innogenetics).

Patients with RBV-induced anemia were administered human recombinant erythropoietin 40,000 IU/week subcutaneously as described in other studies to avoid having to reduce RBV dosing $(14,15)$.

Sustained viral response (SVR) was described as HCV RNA negativity more than 6 months after treatment completion. End-of-treatment response (ETR) was HCV
RNA negativity at week 48. Early virologic response (EVR) was a reduction by at least 2 logs of baseline viral load at week 12 of treatment. Viral response at week 4 (VR4) was established as a reduction by at least $2 \operatorname{logs}$ of viral load at week 4. Rapid viral response (RVR) was defined as negative HCV RNA at 4 weeks. Viral load response at week 2 (VR2) was defined as a reduction by at least $2 \operatorname{logs}$ of baseline viral load at week 2 .

\section{Statistical analysis}

The study design corresponded to a single-cohort, longitudinal follow-up study. Descriptive statistics for qualitative variables were defined using frequency distribution tables and pie charts. Quantitative variables were defined using central tendency statistics, dispersion, and histograms. Using inferential statistics, the main study variable, SVR, was analyzed using the $\chi^{2}$ test and Fischer's exact test for qualitative variables, and the Mann-Whitney and Kruskal-Wallis tests for quantitative variables.

\section{RESULTS}

A total of 57 patients with genotype 1 chronic hepatitis $\mathrm{C}$ were included in the study, although three patients did not complete the study - two did not attend study visits and one was urgently operated upon for complicated abdominal hernia. Therefore, a total of 54 patients completed the follow-up.

Adherence to treatment was very good ( $>80 \%$ of the dose) in $94.4 \%$ of patients; RBV dose was modified in just one patient with anemia and with partial response to erythropoietin.

\section{Baseline characteristics of patients}

Of all 54 patients completing the study, 35 were men $(64.8 \%)$. Mean age at treatment onset was 42.7 years (2665 years). Forty patients were naïve $(74.1 \%), 4$ had relapsed with previous treatment $(7.4 \%)$, and 10 were nonresponders $(18.5 \%)$.

Liver biopsies were performed in $46(85 \%)$. Ten had grade III-IV fibrosis. Baseline viral load was $>800,000$ $\mathrm{IU} / \mathrm{mL}$ in $36(66.7 \%)$. Body mass index (BMI) was $>30$ in 16 patients $(30 \%)$. Thirteen patients had associated cryoglobulinemia (24\%).

Laboratory data are recorded in table I.

\section{End-of-treatment response and sustained viral response}

Per protocol, ETR was 59.3\% (32/54) and SVR was $41 \%(22 / 54)$. By subgroups, SVR was $45 \%$ (18/40) in naïve patients, $75 \%(3 / 4)$ in relapsing patients, and only 
Table I. Baseline characteristics of patients and their relation to SVR

\begin{tabular}{lcccc}
\hline & $\begin{array}{c}\text { Total } \\
n=54\end{array}$ & $\begin{array}{c}\text { SVR } \\
n=22(41 \%)\end{array}$ & $\begin{array}{c}\text { No SVR } \\
n=32(59 \%)\end{array}$ & $p^{*}$ \\
\hline Age (years) & $42.7(26-65)$ & 43.8 & 42 & 0.526 \\
\hline Gender (male/female) & $35 / 19$ & $14 / 8$ & $21 / 11$ & 0.880 \\
\hline BMI (<25/25-30/> 30) & $10 / 28 / 16$ & $5 / 13 / 4$ & $5 / 15 / 12$ & 0.305 \\
\hline $\begin{array}{l}\text { Patient type } \\
\text { (naïve/relapse/ } \\
\text { non-responder) }\end{array}$ & $40 / 4 / 10$ & $18 / 3 / 1$ & $22 / 1 / 9$ & $0.046^{*}$ \\
\hline $\begin{array}{l}\text { Fibrosis } \\
\text { 0-I-I } \\
\text { III-IV }\end{array}$ & 34 & 15 & 19 & 0.243 \\
\hline Baseline viremia (IU/ml) \\
$\leq 800,000$ & 12 & 3 & 9 & \\
$>800,000$ & 36 & 12 & 6 & $0.006 *$ \\
\hline Cryoglobulins & 13 & 6 & 7 & 0.696 \\
\hline ALT (IU/l) & $97(33-416)$ & 94 & 99 & 0.823 \\
\hline AST (IU/l) & $64(24-236)$ & 59 & 67 & 0.481 \\
\hline GGT (IU/) & $71(12-538)$ & 47 & 87 & $0.025^{*}$ \\
\hline Cholesterol (mg/dl) & $176(106-252)$ & 186 & 168 & 0.116 \\
\hline Triglycerides (mg/dl) & $104(33-311)$ & 93 & 112 & 0.237 \\
\hline Ferritin (ng/ml) & $260(7-850)$ & 245 & 270 & 0.648 \\
\hline
\end{tabular}

$10 \%(1 / 10)$ in non-responders to previous treatment (IFN or IFN + RBV).

\section{Predictive factors of response}

The primary objective of the study was to predict SVR by studying baseline characteristics and viral kinetics during treatment. Baseline characteristics and their relation to SVR are recorded in table I. In the comparative analysis, baseline viral load $(p=0.006)$, baseline GGT ( $p$ $=0.025)$, and patient type - nä̈ve, relapsed or non-responder $(\mathrm{p}=0.046)$ - reached statistical significance.

In the study, dynamic factors of viral kinetics such as reduced viral load by $\geq 2 \operatorname{logs}$ at week 2 (VR2), week 4 (VR4), and week 12 of treatment (EVR), and also RVR, reached the greatest statistical significance $(\mathrm{p}=0.001)$ (Table II). VR2 had a PPV of $100 \%$ that gradually decreased during treatment. Conversely, NPV increased steadily to $100 \%$ at week 12 (EVR). Rapid response predicts cure, while lack of response at 12 weeks indicates that the patient is unlikely to respond. In our study, NPV for $\geq 2 \log$ reduction in baseline viral load at week 4 (VR4) was $96.5 \%$.

\section{Study in the naïve patient subgroup}

The comparative study was also conducted in the naïve patient subgroup $(\mathrm{n}=40)$, in which baseline factors
Table II. Viral kinetics response factors at week 2, 4 and 12

\begin{tabular}{lcccc}
\hline & \multicolumn{2}{c}{ Global $(n=53)$} & \multicolumn{2}{c}{ Naïv $(n=40)$} \\
SVR
\end{tabular}

such as viral load $(p=0.002)$, GGT $(p=0.025)$ and BMI $(p=0.033)$ reached statistical significance. Advanced hepatic cirrhosis was associated with poor response to treatment without reaching statistical significance $(p=0.09)$, although this would probably reach significance in a larger series (Table III).

Table III. Baseline characteristics of the naïve patient group in relation to SVR

\begin{tabular}{lcccc}
\hline & Total & SVR & No SVR & \\
& $n=40$ & $n=18(45 \%)$ & $n=22(55 \%)$ & $p^{*}$ \\
\hline Age (years) & $41.88(26-65)$ & 41.61 & 42.09 & 0.886 \\
\hline Gender (male/female) & $25 / 15$ & $10 / 8$ & $15 / 7$ & 0.412 \\
\hline BMI (<25/25-30/> 30) & $6 / 23 / 11$ & $5 / 11 / 2$ & $1 / 12 / 9$ & $0.033^{*}$ \\
\hline Fibrosis & & & & \\
$\begin{array}{l}\text { 0-III } \\
\text { III-IV }\end{array}$ & 26 & 13 & 13 & 0.09 \\
\hline Baseline viremia (IU/ml) & 1 & 1 & 6 & \\
$\leq 800,000$ & 24 & 12 & 4 & $0.002^{*}$ \\
$>800,000$ & $99(21-416)$ & 85 & 110 & 0.314 \\
\hline ALT (IU/L) & $67(19-236)$ & 55 & 77 & 0.140 \\
\hline AST (IU/L) & $75(12-538)$ & 41 & 102 & $0.025^{*}$ \\
\hline GGT (IU/L) & $178(116-251)$ & 189 & 168 & 0.080 \\
\hline Cholesterol (mg/dL) & $98(33-311)$ & 94 & 101 & 0.684 \\
\hline Triglycerides (mg/dL) & 98 (7-850) & 225 & 309 & 0.202 \\
\hline Ferritin (ng/mL) & 270 (n) & & &
\end{tabular}


Viral kinetic factors: VR2, VR4, RVR and EVR also reached statistical significance $(\mathrm{p}=0.001)$, paralleling findings for the whole patient group (Table II).

\section{Adverse effects of treatment}

Although mild adverse effects were common, treatment was not discontinued in any case. Subcutaneous erythropoietin was administered to one patient with hemoglobin under $10 \mathrm{~g} / \mathrm{dL}$. RBV dose was reduced in only one patient owing to partial response to erythropoietin. Neutropenia and platelet deficiency did not require dose adjustment. Significantly altered TSH levels were observed in $3.8 \%$, and these patients were referred to the Endocrinology Clinic. Mood alteration was observed in $53 \%$, and a small proportion of these were referred to the Psychiatry Clinic and started treatment with antidepressants.

\section{DISCUSSION}

SVR rate for naïve patients with genotype 1 chronic hepatitis $\mathrm{C}$ treated with combined pegIFN and RBV for 48 weeks is $42-51 \%(3,4)$. In our series, SVR was $41 \%$ for the entire sample of patients and $45 \%$ for naïve patients. Non-responders had an SVR of 10\%. These results were similar to those reported in the HALT-C and EPIC3 studies for previous non-responders to combined treatment with standard IFN with SVR rates from 12-14\%, which rose to $53 \%$ in case of relapse $(16,17)$.

In our study, we had very high treatment adherence (94.4\%), possibly related to close monthly follow-up for the first 6 months and the use of erythropoietin in anemic patients to avoid having to reduce RBV dose in the first 6 months, as described in previous studies $(14,15)$. This would suggest that the SVR rate in our study should have been even higher, although we did include a significant proportion of patients with severe fibrosis $(22 \%)$, high baseline viral load $(66.7 \%)$, BMI > $30(30 \%)$, and cryoglobulins (24\%), all of them factors associated with poor treatment response.

In recent years, several baseline factors and factors during treatment have been associated with SVR (18). In our study, baseline viral load and GGT reached statistical significance in both the whole patient group and the group of naïve patients. BMI was also a statistically significant factor in the naïve group, although not in the global patient group, possibly due to a larger heterogeneity of the patient group caused by the inclusion of non-responders. In the nä̈ve group fibrosis almost reached statistical significance and would probably do so in a larger sample.

Predictive factors of response with the greatest statistical significance were those associated with viral kinetics. A reduction in viremia $\geq 2 \operatorname{logs} 2$ weeks after treatment onset confirmed SVR. Monitoring at 2 weeks would therefore be justified as patients could be encouraged to continue with treatment. At 4 weeks, we can identify the majority of non-responders and a high percentage of patients with SVR. Patients with a drop of $\geq 2 \operatorname{logs}$ at week 4 have a PPV in our study of $84 \%$, and a NPV of $96.5 \%$, so only a small percentage of patients who continue on treatment will respond, although this should be confirmed in larger patient groups.

It seems, therefore, that two subgroups with different behavior can be defined: one group in which viral load does not drop, and another group with reduced viral load by $\geq 2$ logs, which shows the importance viral suppression speed at week 4 .

The possibility of achieving SVR is related to two factors of viral kinetics: the speed of HCV RNA suppression and the duration of this suppression during treatment, as shown by Ferenci and colleagues (6). For genotype 1, they showed the value of viral load determination at week 4: if RVR was achieved, SVR was $91 \%$, comparable to SVR of more favorable genotypes (genotypes 2 and 3). When there was no RVR, but instead complete EVR, with viral negativization at week 12, the reduction in SVR depended on whether the load at week 4 had dropped by $\geq 2 \operatorname{logs}$ (SVR: $70 \%$ ) or $<2 \operatorname{logs}$ (SVR: $60 \%$ ). In patients with partial EVR, with a drop in week 12 of at least $2 \operatorname{logs}$, but without viral negativization, SVR dropped to $43 \%$, showing the importance of the whole period during which HCV RNA is undetectable for SVR prediction. This means that essentially two patient subgroups can be defined, which could receive different treatment regimens on the basis of their viral kinetics. Regardless of EVR, the longer patients take to achieve HCV RNA negativization the less likely they are to achieve SVR.

Monitoring viral load in the treatment of genotype 1 chronic hepatitis $\mathrm{C}$ is beneficial for the patient. If predictive factors are favorable, the patient will be encouraged to adhere to treatment. From our findings it seems recommendable to extend viral load monitoring to week 2 , and then corroborate the extent of response at week 4, taking into account not only RVR but also VR4, defined as a drop by at least 2 logs in baseline viral load, with a PPV similar to that of RVR, but a higher NPV.

\section{REFERENCES}

1. Shepard CW, Finelli L, Alter MJ. Global epidemiology of hepatitis C virus infection. Lancet Infect Dis 2005; 5: 55.

2. Di Bisciglie A. Hepatitis C. Lancet 1998; 351: 351-5.

3. Manns MP, McHutchinson JG, Gordon SC, Rustgi VK, Shiffman M, Reindollar R, et al. Peginterferon alfa-2b plus ribavirin compared with interferon alfa- $2 b$ plus ribavirin for initial treatment of chronic hepatitis C: a randomized trial. Lancet 2001; 358: 958-65.

4. Fried MW, Shiffman ML, Reddy KR, Smith C, Marinos G, Goncales FL Jr, et al. Combination peginterferon alfa-2a plus ribavirin for chronic hepatitis C virus infection. N Engl J Med 2002; 347: 975-82.

5. Davis G, Wong J, McHutchison J, Manns M, Harvey J, Albrecht J. Early virologic response to treatment with peginterferon alfa-2b plus 
ribavirin in patients with chronic hepatitis C. Hepatology 2003; 3839: 645-52.

6. Ferenci P, Fried MW, Shiffman ML, Smith CI, Marinos G, Goncales FL Jr, et al. Predicting sustained virological responses in chronic hepatitis $\mathrm{C}$ patients treated with peginterferon alfa-2a (40KD)/ribavirin. J Hepatol 2005; 43: 425-33.

7. Fried MW, Hadziyannis SJ, Shiffman M, Messinger D, Zeuzem S. Rapid virological response is a more important predictor of sustained virological response (SVR) than genotype in patients with chronic hepatitis $\mathrm{C}$ virus infection. J Hepatol 2008; 48: S5.

8. Dalgard O, Bjoro K, Hellum KB, Myrvang B, Ritland S, Skaug K, et al. Treatment with pegylated interferon and ribavarin in HCV infection with genotype 2 or 3 for 14 weeks: a pilot study. Hepatology 2004; 4: 1260-5.

9. Von Wagner M, Huber M, Brg T, Hinrichsen H, Rasenack J, Heintges T, et al. Peginterferon-alpha-2a (40kD) and ribavirin fop 16 or 24 weeks in patients with genotype 2 or 3 chronic hepatitis C. Gastroenterology 2005; 129: 5-7.

10. Mangia A, Santoro R, Minerva N, Ricci GL, Carretta V, Persico M, et al. Peginterferon alfa-2b and ribavirin for 12 vs 24 weeks in HCV genotype 2 or 3. N Egl J Med 2005; 352: 2609-17.

11. Zeuzem S, Buti M, Ferenci P, Sperl J, Horsman Y, Cianciara J, et al. Efficacy of 24 weeks treatment with peginterferon alfa-2b plus ribavirinin patients with chronic hepatitis $\mathrm{C}$ infected with genotype 1 and low pre-treatment viremia. J Hepatol 2006; 44: 97-103.

12. Zeuzem S, Awlotsky JM, Lukasiewicz E, Von Wagner M, Goulies I,
Lurie Y, et al. International, multicenter, randomized, controlled study comparing dynamically individualized versus standard treatment in patients with chronic hepatitis C. J Hepatol 2005; 43: 250-7.

13. Sánchez-Tapias JM, Diago M, Escartín P, Enriquez J, RomeroGómez M, Bárcena R, et al. Peginterferon alfa-2a (40KD) plus ribavirin for 48 versus 72 weeks in patients with detectable HCV-RNA at week 4 of treatment. Gastroenterology 2006; 131: 451-60.

14. Pockros PJ, Shiffman ML, Schiff ER, Sulkowski MS, Younossi Z, Dieterich DT, et al., Proactive Study Group. Epoeitin alfa improves quality of life in anemic $\mathrm{HCV}$-infected patients receiving combination therapy. Hepatology 2004; 40: 1450-8.

15. Afdhal N, Dieterich DT, Pockros PJ, Schiff ER, Shiffman ML, Sulkowski MS, et al., Proactive Study Group. Epoetin alfa maintains ribavirin dose in $\mathrm{HCV}$-infected patients: a prospective double-blind randomized, controlled study. Gastroenterology 2004; 126: 1302-11.

16. Shiffman M, Di Bisciegle A, Lindsay K, Morishima C, Wright E, Everson G, et al. Peginterferon alfa $2 \mathrm{a}$ and ribavirin in patients with chronic hepatitis $\mathrm{C}$ who have failed prior treatment. Gastroenterology $2004 ; 126: 1015-23$.

17. Poynard T, Schiff E, Terg R, Moreno Otero R, Flamm S, Schmidt W, et al. Sustained viral response is dependent on baseline characteristic in the retreatment of previous alfa interferon/ribavirin no responders: final results from the EPIC program. J Hepatol 2008; 48(Supl. 2): S369.

18. Alberti A, Chemello L, Benbegnu L. Natural history of hepatitis C. J Hepatol 1999; 31(Supl. 1): 17-24.

\title{
Cinética viral durante el primer mes de tratamiento en pacientes con hepatitis crónica $\mathrm{C}$ genotipo 1
}

\author{
A. Hernández, F. Domper, A. León ${ }^{1}$, R. Lorente, B. López, E. de la Santa, M. Cabanillas, R. Patón, \\ J. Olmedo, M. D. Galván y E. Rodríguez \\ Unidades de Aparato Digestivo y 'de Apoyo a la Investigación. Hospital General de Ciudad Real
}

\section{RESUMEN}

Objetivo: identificar qué factores predicen la respuesta al interferón pegilado alfa- $2 \mathrm{~b}$ y ribavirina en pacientes con hepatitis crónica C genotipo 1 . Se estudió la cinética viral en la semana 2 y 4.

Métodos: se evaluaron de forma prospectiva y consecutiva a los pacientes con hepatitis crónica $\mathrm{C}$ genotipo 1 remitidos a nuestra consulta de hepatología entre enero de 2004 y octubre de 2006, para tratamiento antiviral. Se recogieron datos basales y la viremia se determinó horas antes de la dosis semanal de interferón pegilado por PCR cualitativa y cuantitativa.

Resultados: cincuenta y siete pacientes fueron incluidos aunque 3 fueron excluidos durante el seguimiento. Un 65\% fueron varones $(\mathrm{n}=35)$ con edad media de $42(26-65)$ años. La viremia basal fue $>800.000 \mathrm{UI} / \mathrm{ml}$ en $67 \%(\mathrm{n}=36)$. Se realizó biopsia hepática en $86 \%$ ( $n=46), 22 \%(n=12)$ tenían fibrosis avanzada. 40 fueron naïves, 4 recidivantes y 10 no respondedores. La dosis de ribavirina se modificó por efecto secundario sólo en un paciente. La RFT y la RVS fueron de 59 y $41 \%$, respectivamente. El análisis univariante mostró asociación estadísticamente significativa con RVS de la viremia basal $(p=0,006)$, GGT basal $(p=$ $0,025)$ y el descenso en la viremia $\geq 2$ logaritmos a las 2,4 y 12 semanas $(p=0,001)$. El descenso de la viremia en la semana 2 se asoció con $100 \%$ de RVS y a las 4 semanas el VPP fue $84 \%$ y el VPN 96,5\%. Se realizó un subanálisis en el grupo de pacientes naïves con resultados superponibles.

Conclusiones: en nuestro estudio el descenso de la viremia $\geq$ 2 logaritmos a las 2 semanas de tratamiento aseguró la RVS. A las 4 semanas, identificamos a la gran mayoría de los pacientes no respondedores.

Palabras clave: Hepatitis C. Tratamiento. Interferón pegilado. Viremia. Factores predictores.

\section{INTRODUCCIÓN}

La hepatitis crónica por el virus de la hepatitis $\mathrm{C}$ (VHC) supone una enfermedad infecciosa de gran impacto en nuestro medio y la causa más frecuente de hepatitis crónica, cirrosis y hepatocarcinoma en el mundo occidental (1). En la actualidad la prevalencia de la infección por 
VHC es de 1-2\% en los países desarrollados y es la primera indicación de trasplante hepático en Europa y Estados Unidos (2). El 20\% de los infectados de forma crónica desarrollarán una cirrosis hepática, con un riesgo anual de degenerar en hepatocarcinoma del 1-4\%.

La terapia actual basada en el empleo de interferón pegilado (pegIFN) y ribavirina (RBV) consigue una tasa global de respuesta viral sostenida (RVS) entre 54-56\% mejorando el pronóstico de esta enfermedad $(3,4)$.

Existen ciertas características del paciente, del virus y del tipo de tratamiento empleado que influyen en la respuesta terapéutica. Estas variables nos ayudarían a identificar la mayor o menor probabilidad de respuesta, lo que puede evitar gastos y efectos secundarios innecesarios, favorecen la adhesión del paciente al tratamiento e identifican a aquellos pacientes que se podrían beneficiar de tratamientos más intensivos o prolongados.

La cinética viral (variaciones en la carga viral) durante el tratamiento es el factor predictivo de respuesta más significativo y permite tomar decisiones terapéuticas. La respuesta virológica precoz (RVP) se define como el descenso de al menos 2 logaritmos de la carga viral basal en la semana 12 de tratamiento. Si no se alcanza esta RVP, la probabilidad de RVS es muy baja, con un valor predictivo negativo (VPN) que se acerca al $100 \%$, por lo que en la actualidad las guías clínicas aconsejan la suspensión del tratamiento $(5,6)$. La respuesta viral rápida (RVR) definida como la obtención de carga viral negativa en la semana 4 , es un buen factor pronóstico de la RVS, con un valor predictivo positivo (VPP) del 91\% (7-13). En varios estudios define la duración del tratamiento. Sin embargo, faltan estudios que evalúen el valor de la cinética viral más precozmente.

El objetivo de nuestro estudio ha sido identificar qué factores predicen la respuesta al pegIFN alfa-2b y RBV en pacientes con hepatitis crónica $\mathrm{C}$ genotipo 1 , valorando los factores basales del virus y el huésped, pero sobre todo los factores dinámicos de la cinética viral en la segunda y cuarta semanas de tratamiento.

\section{PACIENTES Y MÉTODOS}

Se evaluaron de forma prospectiva y consecutiva a los pacientes con hepatitis crónica $\mathrm{C}$ genotipo 1 remitidos a la consulta de hepatología de nuestro hospital, entre enero de 2004 y octubre de 2006, que iniciaron tratamiento antiviral con pegIFN alfa- $2 b$ y RBV.

Los criterios de inclusión fueron: edad entre 18 y 70 años, PCR VHC en suero positiva, niveles de ALT superiores al valor normal de nuestro laboratorio $(\leq 40 \mathrm{UI} / \mathrm{l})$ en el último año. Los criterios de exclusión fueron: coinfección con VIH, serología HBsAg o ADN del virus de la hepatitis B positivos, contraindicación para el uso de pegIFN o RBV, cirrosis descompensada, ADVP activos y pacientes recluidos en centros penitenciarios.
Los pacientes recibieron pegIFN alfa-2b (PegIntron; Schering Plough) a dosis de 1,5 microgramos $/ \mathrm{kg}$ de peso, una vez por semana, por vía subcutánea y RBV (Rebetol; Schering Plough) por vía oral, ajustando la dosis según peso (< $65 \mathrm{~kg}$ : $800 \mathrm{mg} /$ día; $65-85 \mathrm{~kg}: 1.000 \mathrm{mg} /$ día; > 85 $\mathrm{kg}$ : $1.200 \mathrm{mg} / \mathrm{día}$ ) en dosis fraccionada mañana y tarde durante 48 semanas.

Se recogieron datos clínicos y analíticos basales, durante el tratamiento en las semanas 2, 4, 8, 12, 16, 20, 24, 36 y 48 , y tras finalizar el tratamiento en la semana 72 . La viremia se valoró unas horas antes de la dosis semanal de pegIFN, en las semanas 2, 4, 12, 24, 48, 60 y 72 .

Hasta octubre de 2005 la carga viral se midió mediante la técnica Cobas Amplicor HCV Monitor 2.0 (límite de detección de $600 \mathrm{UI} / \mathrm{ml}$ ). Las muestras negativas se sometieron a la determinación cualitativa del ARN en Cobas Amplicor HCV Test, versión 2.0 (sensibilidad de 50 $\mathrm{UI} / \mathrm{ml}$ ). A partir de esa fecha la técnica utilizada fue el COBAS Taqman HCV (sensibilidad $15 \mathrm{UI} / \mathrm{ml}$, con determinación cuantitativa hasta $43 \mathrm{UI} / \mathrm{ml})$. Se consideró carga basal baja $\leq 800.000 \mathrm{UI} / \mathrm{ml}(12,13)$.

El genotipo del VHC se determinó mediante la técnica Inno-lipa II (Innogenetics).

En los pacientes que presentaban anemia por el uso de la RBV se les administró eritropoyetina recombinante humana $40.000 \mathrm{UI} / \mathrm{semana}$ por vía subcutánea, con intención de evitar disminuir la dosis de RBV, tal y como han descrito algunos estudios $(14,15)$.

La respuesta viral sostenida (RVS) se definió como negatividad del ARN VHC tras 6 meses de finalizado el tratamiento. La respuesta al final del tratamiento (RFT) como la negatividad del ARN VHC en la semana 48. La respuesta virológica precoz (RVP) como el descenso de al menos 2 logaritmos de la carga viral basal en la semana 12 de tratamiento. La respuesta viral a la semana 4 (RV4) se estableció como el descenso de al menos 2 logaritmos de la carga viral en la semana 4. La respuesta viral rápida (RVR) como la negatividad del ARN VHC a las 4 semanas. La respuesta de la carga viral a la semana 2 (RV2) se definió como el descenso de al menos 2 logaritmos de la carga viral basal en la semana 2 .

\section{Análisis estadístico}

Estudio longitudinal de seguimiento de una cohorte. La estadística descriptiva para variables cualitativas se definió mediante tablas de distribución de frecuencias y gráficos de sectores. Las variables cuantitativas se definieron mediante estadísticos de tendencia central, de dispersión y representación gráfica de histogramas. En la estadística inferencial, la variable principal del estudio (RVS) se analizó utilizando el test de $\chi^{2}$ y exacto de Fisher para variables cualitativas y el test de Mann-Whitney y Kruskal-Wallis para variables cuantitativas. 


\section{RESULTADOS}

Se incluyeron 57 pacientes con hepatitis crónica $\mathrm{C}$ genotipo 1 , aunque tres pacientes no finalizaron el estudio, dos por no acudir a las revisiones y uno por intervención quirúrgica urgente de una hernia abdominal complicada. Por tanto, concluyeron el seguimiento 54 pacientes.

$\mathrm{La}$ adherencia al tratamiento fue muy buena $(>80 \%$ de la dosis) en el 94,4\% de los pacientes, sólo en un paciente se modificó la dosis de la RBV por anemia con respuesta parcial a la eritropoyetina.

\section{Características basales de los pacientes}

De los 54 pacientes que concluyeron el estudio, 35 eran varones $(64,8 \%)$. La edad media al inicio de tratamiento fue de 42,7 años (26-65 años). Cuarenta pacientes eran nä̈ve $(74,1 \%), 4$ con recidiva a tratamiento previo $(7,4 \%)$ y 10 eran no respondedores previos $(18,5 \%)$.

Se realizó biopsia hepática en $46(85 \%)$. Doce tenían fibrosis grado III-IV. La carga viral basal fue $>800.000$ $\mathrm{UI} / \mathrm{ml}$ en $36(66,7 \%)$. El índice de masa corporal (IMC) fue $>30$ en 16 pacientes $(30 \%)$. Presentaban crioglobulinemia asociada 13 pacientes (24\%).

Las características analíticas se desglosan en la tabla I.

Tabla I. Características basales de los pacientes y su relación con la RVS

\begin{tabular}{lcccc}
\hline & $\begin{array}{c}\text { Total } \\
n=54\end{array}$ & $\begin{array}{c}\text { RVS } \\
n=22(41 \%)\end{array}$ & $\begin{array}{c}\text { No RVS } \\
n=32(59 \%)\end{array}$ & $p^{*}$ \\
\hline Edad (años) & $42,7(26-65)$ & 43,8 & 42 & 0,526 \\
\hline Sexo (varón/mujer) & $35 / 19$ & $14 / 8$ & $21 / 11$ & 0,880 \\
\hline IMC (<25/25-30/> 30) & $10 / 28 / 16$ & $5 / 13 / 4$ & $5 / 15 / 12$ & 0,305 \\
\hline $\begin{array}{l}\text { Tipo paciente } \\
\text { (naïve/recidiva/ }\end{array}$ & & & & \\
no respondedor) & $40 / 4 / 10$ & $18 / 3 / 1$ & $22 / 1 / 9$ & $0,046^{*}$ \\
\hline Fibrosis & & & & \\
0-I-II & 34 & 15 & 19 & 0,243 \\
III-IV & 12 & 3 & 9 & \\
\hline Viremia basal (IU/ml) & 18 & 12 & 6 & $0,006^{*}$ \\
$\leq 800,000$ & 36 & 10 & 26 & \\
$>800,000$ & 13 & 6 & 7 & 0,696 \\
\hline Crioglobulinas & $97(33-416)$ & 94 & 99 & 0,823 \\
\hline ALT (IU/l) & $64(24-236)$ & 59 & 67 & 0,481 \\
\hline AST (IU/l) & $71(12-538)$ & 47 & 87 & $0,025^{*}$ \\
\hline GGT (IU/l) & $176(106-252)$ & 186 & 168 & 0,116 \\
\hline Colesterol (mg/dl) & $104(33-311)$ & 93 & 112 & 0,237 \\
\hline Triglicéridos (mg/dl) & $260(7-850)$ & 245 & 270 & 0,648 \\
\hline Ferritina (ng/ml) & & & &
\end{tabular}

\section{Respuesta al final del tratamiento y respuesta viral sostenida}

Por protocolo la RFT fue del 59,3\% (32/54) y la RVS de $41 \%$ (22/54). Por subgrupos la RVS fue del $45 \%$ (18/40) en los naïve, del 75\% (3/4) en los recidivas y sólo del $10 \%(1 / 10)$ en los no respondedores a tratamientos previos (IFN o IFN con RBV).

\section{Factores predictores de respuesta}

El objetivo principal del estudio fue la predicción de la RVS estudiando características basales y la cinética viral durante el tratamiento. Las características basales y su relación con la RVS se desglosan en la tabla I. En el análisis comparativo alcanzaron significación estadística la carga viral basal $(p=0,006)$, la GGT basal $(p=0,025)$ y el tipo de paciente: nä̈ve, recidiva, no respondedor $(\mathrm{p}=$ $0,046)$.

En el estudio alcanzaron mayor significación estadística $(\mathrm{p}=0,001)$ los factores dinámicos de cinética viral como el descenso de la carga viral $\geq 2$ logaritmos en la semana 2 (RV2), semana 4 (RV4) y semana 12 de tratamiento (RVP), al igual que la RVR (Tabla II). La RV2 tuvo un VPP del 100\%, que fue disminuyendo conforme se continuaba con el tratamiento. De forma inversa el VPN fue progresivamente mayor hasta alcanzar el $100 \%$ en la semana 12 (RVP). Una respuesta rápida pronostica la curación mientras que la falta de respuesta tras 12 se-

Tabla II. Factores de respuesta de la cinética viral a la semana 2,4 y 12

\begin{tabular}{lcccc}
\hline & \multicolumn{2}{c}{ Global $(n=53)$} & \multicolumn{2}{c}{ Naïve $(n=40)$} \\
RVS
\end{tabular}


manas indica que el paciente no va a responder. En nuestro estudio el VPN del descenso $\geq 2$ log de la carga viral basal en la semana 4 (RV4) fue de 96,5\%.

\section{Estudio en el subgrupo de pacientes naïve}

Se realizó también el mismo estudio comparativo en el subgrupo de pacientes naïve $(\mathrm{n}=40)$ alcanzando significación estadística los factores basales como la carga viral $(p=0,002)$, la GGT $(p=0,025)$ y el IMC $(p=0,033)$. La fibrosis hepática avanzada se asoció con peor respuesta al tratamiento sin alcanzar significación estadística $(\mathrm{p}=$ 0,09 ) aunque probablemente la obtuviera al aumentar el número de pacientes (Tabla III).

También presentaron significación estadística $(\mathrm{p}=$ 0,001 ) los factores de la cinética viral RV2, RV4, RVR y RVP de forma paralela a lo comentado anteriormente con el global de los pacientes (Tabla II).

Tabla III. Características basales del grupo de pacientes naïve y su relación con la RVS

\begin{tabular}{lcccc}
\hline & $\begin{array}{c}\text { Total } \\
n=40\end{array}$ & $\begin{array}{c}\text { RVS } \\
n=18(45 \%)\end{array}$ & $\begin{array}{c}\text { No RVS } \\
n=22(55 \%)\end{array}$ & $p^{*}$ \\
\hline Edad (años) & $41,88(26-65)$ & 41,61 & 42,09 & 0,886 \\
\hline Sexo (varón/mujer) & $25 / 15$ & $10 / 8$ & $15 / 7$ & 0,412 \\
\hline IMC (<25/25-30/> 30) & $6 / 23 / 11$ & $5 / 11 / 2$ & $1 / 12 / 9$ & $0,033^{*}$ \\
\hline Fibrosis & & & & \\
$\begin{array}{l}\text { 0-I-II } \\
\text { II-IV }\end{array}$ & 26 & 13 & 13 & 0,09 \\
\hline Viremia basal (IU/ml) & 1 & 1 & 6 & \\
$\leq 800.000$ & 16 & 12 & 4 & $0,002^{*}$ \\
$>800.000$ & 24 & 6 & 18 & \\
\hline ALT (IU/l) & $99(21-416)$ & 85 & 110 & 0,314 \\
\hline AST (IU/l) & $67(19-236)$ & 55 & 77 & 0,140 \\
\hline GGT (IU/l) & $75(12-538)$ & 41 & 102 & $0,025^{*}$ \\
\hline Colesterol (mg/dl) & $178(116-251)$ & 189 & 168 & 0,080 \\
\hline Triglicéridos (mg/dl) & $98(33-311)$ & 94 & 101 & 0,684 \\
\hline Ferritina (ng/ml) & $270(7-850)$ & 225 & 309 & 0,202 \\
\hline
\end{tabular}

\section{Efectos adversos del tratamiento}

Ninguno de los pacientes incluidos suspendió el tratamiento por efectos adversos, que fueron frecuentes, aunque en la mayoría de los casos fueron leves. Se pautó eritropoyetina subcutánea en los pacientes con descenso de la hemoglobina por debajo de $10 \mathrm{~g} / \mathrm{dl}$. Sólo en un paciente se disminuyó la dosis de RBV por respuesta parcial a la eritropoyetina. La neutropenia y la plaquetopenia no requirieron ajuste de dosis. Se observó alteración significativa en las cifras de TSH en un 3,8\%. Estos pacientes fueron remitidos a la consulta de endocrinología. Presentaron alteración en el estado de ánimo un 53\%, un pequeño porcentaje de estos fueron remitidos a la consulta de psiquiatría e iniciaron tratamiento con antidepresivos.

\section{DISCUSIÓN}

La tasa de RVS para pacientes naïve con hepatitis crónica $\mathrm{C}$ genotipo 1 , con la combinación de pegIFN y RBV durante 48 semanas, es del 42-51\% $(3,4)$. En nuestra serie la RVS fue del $41 \%$ para la totalidad de los pacientes y en los pacientes naïve fue del $45 \%$. En los no respondedores la RVS fue del $10 \%$, semejante a los resultados de los estudios HALT-C y EPIC3, en pacientes no respondedores previos a tratamiento combinado con IFN estándar que refieren tasas de RVS entre 12-14\% y aumenta hasta $53 \%$ si es recidivante $(16,17)$.

En nuestro estudio la adherencia al tratamiento fue muy alta $(94,4 \%)$, en posible relación al estrecho seguimiento mensual durante los primeros 6 meses y al uso de eritropoyetina cuando los pacientes presentaron anemia para evitar reducir dosis en los primeros 6 meses, tal y como está descrito en estudios previos $(14,15)$. Esto hace pensar que la tasa de RVS de nuestro estudio debería haber sido algo mayor, pero también hay que tener en cuenta que incluimos un porcentaje importante de pacientes con fibrosis severa (22\%), carga viral basal alta $(66,7 \%)$, IMC > $30(30 \%)$ y crioglobulinas $(24 \%)$, factores que se han asociado a una peor respuesta al tratamiento.

En los últimos años se han descrito factores basales y durante el tratamiento que se relacionan con la RVS (18). En nuestro estudio, tanto en la totalidad de los pacientes como en el subgrupo de pacientes naïve alcanzaron significación estadística la carga viral basal y la GGT. En los pacientes naïve fue también estadísticamente significativo el IMC, mientras no fue significativo al incluir la totalidad de los pacientes posiblemente debido a la mayor heterogenicidad del grupo al incluir los pacientes no respondedores. La fibrosis, en los pacientes naïve, se acercaba a la significación estadística sin llegar a alcanzarla, esa tendencia posiblemente pudiera conseguir significación de ampliarse la muestra.

Los factores predictores de respuesta con mayor significación estadística fueron aquellos relacionados con la cinética viral. El descenso de la viremia $\geq 2$ logaritmos a las 2 semanas de iniciado el tratamiento aseguró la RVS. Por tanto, la monitorización a la semana 2 estaría justificada dado que permite estimular a los pacientes para continuar con el tratamiento. A las 4 semanas identificamos a la gran mayoría de los no respondedores y a un elevado porcentaje de los pacientes con RVS. Los pacientes con descenso $\geq 2$ logaritmos en la semana 4 tienen en nuestro estudio un VPP de $84 \%$, y un VPN de $96,5 \%$, por lo que solo un pequeño porcentaje de pacientes que continúen 
con el tratamiento estándar va a responder. Esto convendría confirmarlo con estudios con mayor número de pacientes.

Parece que el no descenso de la carga viral y el descenso de $\geq 2$ logaritmos podrían marcar dos subgrupos con comportamiento diferente y nos indica la importancia de la rapidez en la supresión viral en la semana 4.

Las posibilidades de conseguir una RVS está relacionada con dos factores de la cinética viral: la rapidez de supresión del ARN VHC y el tiempo de duración de la supresión durante el tratamiento como demostraron $\mathrm{Fe}$ renci y cols. (6). En el genotipo 1 demostraron el valor de la determinación de la carga viral en la semana 4: si se conseguía una RVR, la RVS era del 91\%, comparable a la RVS de genotipos más favorables (genotipos 2 y 3 ). Cuando no existía RVR pero sí RVP completa, con negativización del virus en la semana 12, la RVS descendía dependiendo si la carga a la semana 4 había disminuido $\geq 2$ logaritmos (RVS: 70\%) o $<2$ logaritmos (RVS: $60 \%$ ). En los pacientes con RVP parcial, con bajada en la semana 12 de al menos 2 logaritmos pero sin llegar a negativizar el virus, la RVS baja a 43\%, lo que demostraba también la importancia del periodo tiempo total durante el cual permanece indetectable el ARN VHC en la predicción de la RVS. Todo ello, permite definir subgrupos de pacientes que podrían recibir pautas de tratamientos diferentes según su cinética viral. Independientemente de la RVP, cuanto más tarda el paciente en negativizar el ARN VHC menor probabilidad tiene de RVS.

La monitorización de la carga viral en el tratamiento de la hepatitis crónica $\mathrm{C}$ genotipo 1 aporta beneficios para el paciente. Si existen factores predictivos favorables el paciente intentará una mayor adhesión al tratamiento. Según nuestros resultados parece que sería de ayuda ampliar la monitorización de la carga viral a la semana 2 y corrobora la importancia de la respuesta en la semana 4, teniendo en cuenta no solamente la RVR sino la RV4, definida como el descenso de al menos 2 logaritmos de la carga viral basal, con un VPP similar a la RVR, pero un VPN mayor. 